\title{
Exploiting shoot tips as an efficient explant for in vitro regeneration of cucumber (Cucumis sativus $\mathbf{L}$.)
}

\author{
Faiz Ahmad Joyia*, Ghulam Mustafa, Rubab Zahra, Saddam Munawar, \\ Muhammad Nisar Anjum and Muhammad Sarwar Khan \\ Centre of Agricultural Biochemistry and Biotechnology (CABB), University of Agriculture, Faisalabad-Pakistan \\ *Corresponding author's email:faizahmad1980@gmail.com \\ Citation \\ Faiz Ahmad Joyia, Ghulam Mustafa, Rubab Zahra, Saddam Munawar, Muhammad Nisar Anjum and Muhammad \\ Sarwar Khan. Exploiting shoot tips as an efficient explant for in vitro regeneration of cucumber (Cucumis sativus \\ L.). Pure and Applied Biology. Vol. 8, Issue 2, pp1824-1829. http://dx.doi.org/10.19045/bspab.2019.80126
}

Received: $16 / 04 / 2019$

Revised: 20/06/2019

Accepted: $27 / 06 / 2019$

Online First: 29/06/2019

\section{Abstract}

A proficient and speedy in vitro regeneration is a prerequisite for genetic modification of plants. The described protocol presents an efficient and practicable procedure for regeneration and multiple shoots induction by using shoot tips as explants for cucumber (Cucumis sativus L.). First, aseptic seedlings were established and shoot tips were excised from those seedlings. The cucumber seedlings used after 7 days of germination were found to be the best source of explants. Theses shoot tips were placed on MS medium supplemented with different concentrations of Benzyl amino purine (BAP) $(0.5-2.5 \mathrm{mg} / \mathrm{L})$. It was observed that MS medium augmented with $1.5 \mathrm{mg} / \mathrm{L}$ BAP resulted in maximum shoots formation. By increasing BAP beyond $1.5 \mathrm{mg} / \mathrm{L}$, rate of shoots formation was decreased. For rooting purpose, Indole Butyric Acid (IBA) (0.5-2.5mg/L) was used. Shoots greater than $2 \mathrm{~cm}$ in size were shifted to rooting medium. Best roots development took place on MS medium having $1 \mathrm{mg} / \mathrm{L}$ IBA. The plantlets with well-developed roots were shifted to peat moss containing pots and gradually acclimated to soil. This in vitro regeneration protocol can be used for genetic transformation of cucumber in future.

Keywords: BAP; Cucumber; IBA; In vitro regeneration; Shoot tips

\section{Introduction}

Cucumber (Cucumis sativus L.), is a member of family Cucurbitaceae and genus Cucumis. This genus is comprised of 52 species [1]. Cucumbers and melons are two most economically important food crops. Cucumber has gained much attention to be used as model plant for research purpose in family Cucurbitaceae because its genome sequence is available and efforts have been made to transform its genome [2]. It is a monoecious vegetable with vining type stem which is grown worldwide [3] and being used in several bouquet perfumes. Cucumber has tonic, refrigerant and diuretic seeds [4] which have many applications in cosmetics and medicine. Strong antioxidant potential of cucumbers makes them suitable to irritated skin caused by sun burn for its soothing and chilling effect [5].

Cucumber is a vegetable crop of great importance, susceptible to various viral and bacterial diseases which limit its average yield. Moreover, cucumber is vulnerable to 
several fungal pathogens especially when cultivated in tunnels where semi-closed environment with elevated humidity and temperature regimes maximize the chances of fungal infestation. Hence, production of cucumber lines resistant to viral, bacterial and fungal diseases is desirable in all Cucumber growing areas around the globe. Cucumber has narrow genetic base makes the use of classical breeding a bit tedious for cucumber varietal improvement. Crossing incompatibility is also a barrier in undertaking inter-specific hybridization of cucumber with other members of the genus Cucumis and family Cucurbitaceae. Hence, the development of somaclonal variants, somatic hybrids and transgenic lines are some practical options available for improvement of cucumber crop [6,7]. All these methodologies need highly effective tissue culture regeneration system for crop improvement [8, 9]. As modern biotechnological techniques including gene transfer technologies are being used for crop improvement [10]. The aim of present research was to standardize the concentrations of the plant growth regulators (PGRs) for improving in vitro regeneration of cucumber which can be used to produce transgenic cucumber lines in future through gene transfer technologies.

Materials and methods

In vitro establishment of aseptic seedlings
Seeds of cucumber variety namely, "Desi" were obtained from horticulture department of University of Agriculture, Faisalabad. First, healthy seeds were washed 3-4 times with double distilled water. Then, seeds were treated with $70 \%$ ethanol for 2 minutes, $0.2 \%$ mercuric chloride having 2 drops of tween-20 for 5 minutes. Finally, seeds were washed with sterile distilled water 5-6 times until all the mercuric chloride was removed. Then, seeds were de-coated using autoclaved forceps and placed on MS medium (Murashige and Skoog) without any growth regulators and incubated in dark at $25 \pm 2{ }^{\circ} \mathrm{C}$ for the in vitro establishment of seedlings.

\section{Culture medium and conditions}

The media employed in the current study contained Murashige and Skoog (MS) salts [11] which were then supplemented with different concentrations and combinations of PGRs namely 6-benzylaminopurine (BAP) $(0.5-2.5 \mathrm{mg} / \mathrm{L})$, zeatin BAP $(2.0 \mathrm{mg} / \mathrm{L})$, and indole-3-butyric acid (IBA) $(0.5-2.5 \mathrm{mg} / \mathrm{L})$ as given in (Table 1). At the end, $\mathrm{pH}$ was adjusted to 5.8 before autoclaving.

\section{Explant attainment}

In vitro grown seedlings of cucumber after 7 , 8 and 9 days of culture were used to obtain shoot tips. Shoot tips were placed on MS media having $0.5-2.5 \mathrm{mg} / \mathrm{L}$ BAP and $2 \mathrm{mg} / \mathrm{L}$ zeatin. By using shoot tips as explants, direct shoots induction was observed by providing $25 \pm 2{ }^{\circ} \mathrm{C}$ under 16 hours light and 8 hours dark conditions.

Table 1. Exact concentrations of different plant growth regulators (PGRs) used in this study

\begin{tabular}{|c|c|c|}
\hline Sr. No. & $\begin{array}{c}\text { Shooting media } \\
\text { Conc. }(\mathbf{m g} / \mathbf{L})\end{array}$ & $\begin{array}{c}\text { Rooting media } \\
\text { Conc. (mg/L) }\end{array}$ \\
\hline 1 & $\begin{array}{c}\text { BAP (0.5) } \\
\text { Zeatin (2.0) }\end{array}$ & IBA (0.5) \\
\hline 2 & $\begin{array}{c}\text { BAP (0.1) } \\
\text { Zeatin (2.0) }\end{array}$ & IBA (1.0) \\
\hline 3 & $\begin{array}{c}\text { BAP (1.5) } \\
\text { Zeatin (2.0) }\end{array}$ & IBA (2.5) \\
\hline 4 & $\begin{array}{c}\text { BAP (2.0) } \\
\text { Zeatin (2.0) }\end{array}$ & IBA (2.5) \\
\hline 5 & $\begin{array}{c}\text { BAP (2.5) } \\
\text { Zeatin (2.0) }\end{array}$ \\
\hline
\end{tabular}




\section{Rooting and acclimatization}

Regenerated shoots greater than $2 \mathrm{~cm}$ in length were shifted to rooting medium having different concentrations of IBA. Plants were placed on the rooting medium for 2-3weeks till vigorous rooting. Firstly, roots were washed with tap water. Well-developed rooted plants were shifted to plastic pots having autoclaved peatmoss. Polythene bags were used to cover the pots to minimize evapo-transpirational losses. Gradually, bags were removed after some weeks and plants were shifted to green house for acclimatization.

\section{Results}

In vitro growing seedlings were used as source of explants. The 7, 8- and 9-days old seedlings were used for this purpose. The age of seedlings was found to be an important factor in the determination of regeneration rate. The 7 days old seedlings responded well and maximum for regeneration. By increased ages of seedlings more than 7 days, rate of regeneration was decreased. Moreover, shoot tips proved to be a reasonable explant for in vitro regeneration of cucumber.

\section{Multiple shoots regeneration}

Shoot tips originating in between the cotyledons were carefully excised from in vitro growing seedlings. When shoots tips were placed on regeneration medium having $2 \mathrm{mg} / \mathrm{L}$ zeatin, it resulted in the development of direct shoots regeneration. But rate of shoots development was very slow. It was observed that multiple shoots induction took place by using MS medium augmented with different concentrations of BAP (0.5$2.5 \mathrm{mg} / \mathrm{L}$ ) and $2 \mathrm{mg} / \mathrm{L}$ zeatin (Table 1 ). By using different concentrations of BAP, rate of shoots formation was different. However, response of shoots induction on medium having $0.5 \mathrm{mg} / \mathrm{L}$ BAP was very slow which increased with the increase in BAP concentration. It was recorded that MS medium augmented with $1.5 \mathrm{mg} / \mathrm{L}$ BAP produced maximum number of shoots
(Figure 1) as compared to other concentrations of BAP being used. The number of shoot regeneration decreased by using concentrations above $1.5 \mathrm{mg} / \mathrm{L}$ BAP. Concentration of BAP being used was an important factor in determination of shoots regeneration rate.

\section{Roots induction}

For rooting purpose, elongated shoots greater than $2 \mathrm{~cm}$ in length were cultured on MS medium having different concentrations of IBA $(0.5-2.5 \mathrm{mg} / \mathrm{L})$ (Table 1$)$. It was observed that adventitious roots emerged from base of the shoots directly. By using different concentrations of IBA, variable number of roots was observed however, maximum roots were obtained by using $1.0 \mathrm{mg} / \mathrm{L}$ IBA. Rate of roots formation increased up to $1.0 \mathrm{mg} / \mathrm{L}$ concentration and beyond this level, number of roots regeneration was decreased.

\section{Discussion}

For the purpose of in vitro direct shoots formation in Cucurbitaceae, BAP and zeatin are found to be effective. By using shoot tips of cucumber as explants, maximum number of shoots were produced on medium having 1.0mg/L BAP [12]. Lee et al. [13] reported shoot bud regeneration in winter squash (Cucurbita maxima) using MS medium supplemented with BAP. The BAP was found to be the most important plant growth regulator for shoots formation in squash (Cucurbita pepo) by using $1.0 \mathrm{mg} / \mathrm{L}$ BAP concentration [14]. Similarly, Agarwal and Kamal [15] reported that use of BAP was necessary for shoot formation in bitter gourd (Momordica charantia). Similar, results were found in bottle guard (Lagenaria siceraria) where BAP $2.0 \mathrm{mg} / \mathrm{L}$ played an important role in enhancement of shoots regeneration [16]. Later, induction of multiple shoot buds from cotyledonary explants was observed in watermelon (Citrullus lanatus) using BAP [17]. The results reported in the present study are in line with the above cited literature and BAP $1.5 \mathrm{mg} / \mathrm{L}$ has been found effective for 
inducing multiple shoots from shoot tips (Figure 1).

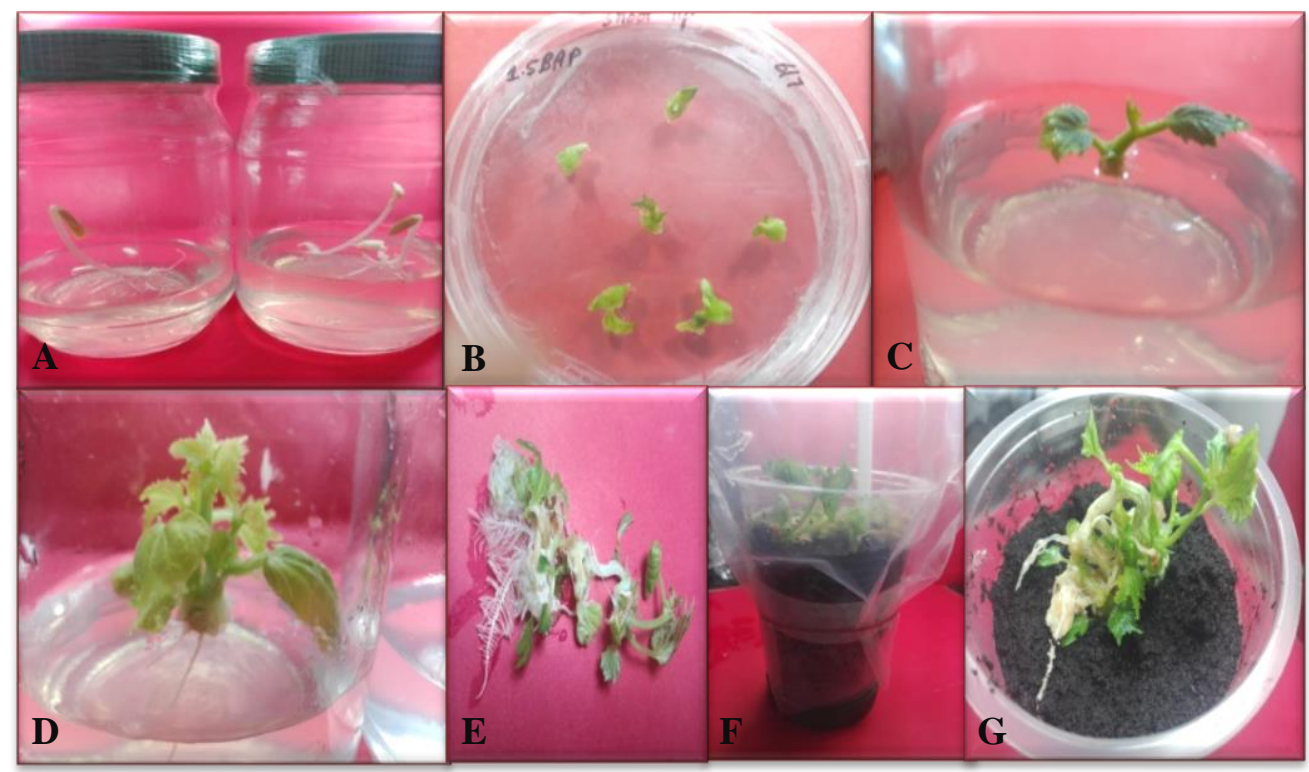

Figure 1. Stepwise in vitro regeneration of cucumber. (A) Seven days old seedlings grown from surface sterilized de-coated seeds on MSO medium (B) Excised shoot tips placed on SIM (C) Shoots growing from shoot tips on SIM (D) Shoots multiplication on SIM (E) Roots development on medium having IBA (F) Plantlets shifted into peat moss and covered with polythene bags (G) Plants growing in peat moss after removing polythene bags

Indole Butyric Acid (IBA) has been found effective in root induction. Selvaraj et al. [18] reported that IBA at concentration of $0.7 \mathrm{mg} / \mathrm{L}$ was effective in roots induction for cucumber. It is reported that IBA plays an important role in roots induction for the other members of the family Cucurbitaceae like teasle gourd and winter melon [19, 20]. Similarly, Rai et al. [21] used IBA for rooting purpose in $M$. dioica. Some authors have reported zeatin to encourage adventitious shoot formation in cucumber at a low concentration as described in present study [22-24].

\section{Conclusion}

The cucumber (Cucumis sativus L.) being vulnerable to various biotic stresses needs to be improved using modern biotechnological tools including genetic transformation which requires efficient tissue culture system in most cases. The reported method employed shoot tips as proficient explants for regeneration of multiple shoots when cultured on MS medium supplemented with $1.5 \mathrm{mg} / \mathrm{L}$ BAP and $2 \mathrm{mg} / \mathrm{L}$ zeatin. This protocol may help in genetic transformation of cucumber.

\section{Authors' contributions}

Conceived and designed the experiments: FA Joyia \& MS Khan, Performed the experiments: R Zahra \& MN Anjum, Analyzed the data: FA Joyia \& S Munawar, Contributed reagents/ materials/ analysis tools/ facilities: G Mustafa \& MS Khan, Wrote the paper: FA Joyia, G Mustafa \& R Zahra.

\section{Acknowledgement}

Authors would like to acknowledge University of Agriculture Faisalabad (UAF), 
Pakistan for providing facilities for this study.

\section{References}

1. Sangeetha $P$ and Venkatachalam $P$. 2014. Induction of direct shoot organogenesis and in vitro flowering from shoot tip explants of cucumber (Cucumis sativus L. cv. 'Green long'). In Vitro Cell Developmental BiolPlant 50(2): 242-248.

2. Baskaran P, Soos V, Balazs E and Van Staden J. 2016. Shoot apical meristem injection: a novel and efficient method to obtain transformed cucumber plants. $S$ Afr $J \quad$ Bot 103: 210-215. https://www.sciencedirect.com/science/ article/pii/S0254629915003944

3. Abu-Romman SM, Al-Hadid KA and Arabiyyat AR, 2015. Kinetin is the most effective cytokinin on shoot multiplication from cucumber. J Agri Sci 7(10):159-165.

http://www.ccsenet.org/journal/index.ph $\mathrm{p} / \mathrm{jas} /$ article/view/51425

4. Ugandhar T, Venkateshwarrlu M, Begum G, Srilatha $\mathrm{T}$ and Jaganmohanreddy K. 2011. In Vitro plant regeneration of Cucumber (Cucumis sativum (L.) from cotyledon and hypocotyl explants. Sci Res Rep 1(3): 164-169.

5. Budhiraja H, Gupta RK and Nand P. 2014. Formulation and characterization of Cucumis sativus extract in the treatment of acne. World J Pharmacy Pharmaceutical Sci 3(12): 1043-1057.

6. Joyia FA and Khan MS. 2013. In vitro micropropagation studies of elite Pakistani rice varieties. Int J Agri Biol 15:27-33.

7. Grozeva S and Velkov N. 2014. In vitro plant regeneration of two cucumber (Cucumis sativum L.) genotypes: effects of explant types and culture medium. Genetika 46(2): 485-493.
8. Wang J, Zhang S, Wang X, Wang L, Xu H, Wang X, Shi Q, Wei M and Yang F. 2012. Agrobacterium-mediated transformation of cucumber (Cucumis sativus L.) using a sense mitogenactivated protein kinase gene (CsNMAPK). Plant Cell Tiss Org Cult 113, 269-277.

9. Todorova, V., Grozeva, S., Rodeva, V. and Masheva, S. 2013. Breeding evaluation of pepper lines obtained by in vitro anther culture. Genetika 45(2): 601-610.

10. Gaba V, Zelcer A and Gal-On A. 2004. Cucurbit biotechnology- the importance of virus resistance. In Vitro Cell \& Developmental Biol -Plant 40: 346-358.

11. Murashige T and Skoog F. 1962. A revised medium for rapid growth and bioassays with tobacco tissue cultures. Plant Physiol 15:473-497.

12. Vasudevan A, Selvaraj N, Sureshkumar P and Ganapathi A. 2001. Multiple shoot induction from the shoot tip explants of cucumber (Cucumis sativus L.). Cucurbit Genetics Cooperative Report. 24: 8-12.

13. Lee YK, Chung WI and Ezura H. 2003. Efficient plant regeneration via organogenesis in winter squash (Cucurbita maxima Duch.). Plant Sci 164: 413-418.

14. Ananthakrishnan G, Xia X, Elman C, Singer S, Paris HS, Gal-On A and Gaba V. 2003. Shoot production in squash (Cucurbita pepo) by in vitro organogenesis. Plant Cell Rep 21: 739 746.

15. Agarwal $\mathrm{M}$ and Kamal R. 2004. In vitro propagation of Momordica charantia L. Ind J Biotechnol 3: 426-430.

16. Saha S, Mori H and Hattori K. 2007. Synergistic effect of kinetin and benzyl adenine plays a vital role in high frequency regeneration from cotyledonary explants of bottle gourd 
(Lagenaria siceraria) in relation to ethylene production. Breeding Sci 57: 197-202.

17. Ganasan K and Huyop F. 2010. In vitro regeneration of Citrullus lanatus cv. Round dragon. J Biol Science 10: 131137.

18. Selvaraj N, Vasudevan A, Manickavasagam V, Kasthurirengan S. and Ganapathi A. 2007. High frequency shoot regeneration from cotyledon explants of cucumber via organogenesis. Scientia Horticulturea 112: 2-8.

19. Nabi SA, Rashid MM, Al-Amin M. and Rasul MG. 2002. Organogenesis in teasle gourd (Momordica dioica Roxb.). Plant Tiss Cult Biotechnol 12: 173-180.

20. Müller B and Sheen J. 2007. Advances in cytokinin signaling. Science 318(5847): 68-69.

21. Rai GK, Singh M, Rai NP, Bhardwaj DR and Kumar S. 2012. In vitro propagation of spine gourd (Momordica dioica Roxb.) and assessment of genetic fidelity of micropropagated plants using RAPD analysis. Physiol Mol Biol Plants 18: 273-280.

22. Selvaraj N, Vasudevan A, Manickavasagam $\mathrm{M}$ and Ganapathi A. 2006. In vitro organogenesis and plant formation in cucumber. Biologia Plantarum 50(1): 123-126.

23. Venkatachalam $P$, Jinu U, Sangeetha $P$, Geetha N and Sahi SV (2018) High frequency plant regeneration from cotyledonary node explants of Cucumis sativus L. cultivar 'Green Long' via adventitious shoot organogenesis and assessment of genetic fidelity by RAPD-PCR technology. 3Biotech 8: 60

24. Wang Y, Zhou Q, Zhu G, Wang S, Ma Y, Miao H, Zhang S, Huang S, Zhang Z $\& \mathrm{Gu}$ X (2018). Genetic analysis and identification of a candidate gene associated with in vitro regeneration ability of cucumber. Theor Appl Genet 131(12):2663-2675. 